\title{
千葉県の病院外来部待合空間に設置された 植物の現状調査と評価に関する研究
}

\section{上野 勝 1) - 岩崎 寛 1)}

1）千葉大学大学院園芸学研究科

摘要 : 近年, 植物の保有する植物のストレス緩和効果が注目され, 療法的効果を目的とした緑化が病院でも進められつつあるが，十 分であるとは言い難い。また患者や職員の滞在時間が最も長く, ストレスを感じやすい屋内の植物に関する詳細な調査はされてい ないため, アンケート調査と現地調査により実態を調べた。その 結果, 病院は植物を患者のために設置しているが, 現地では視界 に入りにくい場所に設置されているものが多く，「ガーデンホス ピタル」構想の目的である植物のストレス緩和効果を期待できな い現状が明らかになった。

キーワード : 病院緑化, 外来部待合空間, アンケート調査, 現地 調査, 設置場所

\section{1. はじめに}

近年, 植物の保有するストレス緩和効果が注目され, 療法 的効果を期待した緑化が進められている ${ }^{3)}$ 。（独）国立病院 機構が 2005 年に打ち出した「ガーデンホスピタル」構想は, 病院内外の緑化を進めることで, 患者や職員の精神的なス卜 レス軽減を目的としたものであるが，実際の病院において， この構想が十分に進んでいるとは言いがたい状況である9）

既往の研究では屋外や屋上の緑化の現状 $1,2,4,7)$ が報告され ているが，屋内の植物に関する詳細な調查はほとんど見られ ない。しかし，患者や職員の多くは屋内に滞在している時間 のほうが長く, 特に外来部待合は多くの人が集まることや, 待ち時間も長いことから，ストレスを感じやすい空間である と考えられる。そこで本研究では，これまで詳細に調査され ていない外来部待合空間における植物の現状調査と, それら の評価や問題点について考察することを目的とした。

\section{2. 調查方法}

\section{1 研究対象}

大規模の病院ほど，外来の待ち時間は長いと考えられる。 そこで本研究では（財）日本医療機能評価機構の病院審査種 別5)を参考に, 大規模病院と分類される 200 床以上の病院を 取り上げ, これに当てはまる千葉県内の 100 力所の病院 ${ }^{8)}$ 対象とした。

\section{2 研究方法}

調査は現地調查およびアンケート調査を実施した。現地調 查では，外来部待合空間に設置された植物の名前，樹高など とともに，椅子に座った状態でみえる植物の状態を平面的， 立体的に捉えた図を作成した。また，病院の平面図を作成し 植物の配置や，テレビや絵画など患者のために設置されてい るアメニティの位置もプロットした。

アンケート調査では，現地調査では分からない設置目的や 管理の状況などを質問項目とした。アンケートは 100 病院に 郵送し，37 通回収した（回収率 $37 \%$ ）。

\section{3 用語説明}

病院の外来や待合についての用語は正確に定義されていな い。「待合」の言葉でも受付や会計を含むもの，含まないも のなど様々である 6)。よって本研究ではそれぞれの用語につ いて表-1のように定義する。

\section{3. 結果と考察}

\section{1 現地調査結果}

対象とした 100 病院の内 20 力所の病院において現地調查 を行った。その結果，外来部待合空間に植物が置かれていた のは 15 力所の病院であった。図-1に植物の詳細な配置場所 をまとめた結果を示した。図をみると，壁際周辺に設置され ている場合が $54 \%$ と最も多く, これは, 壁際には椅子が設置 されている場合が多いことや，人の動線を遮らないことなど が原因であると考えられた。このことは人が多く集まる外来 部待合にとって重要な要件であると考えられた。

また植物の設置場所を待合別にみると, 各診療科待合が 39 $\%$ と最も多く, 次いで総合待合が $24 \%$, 複合待合が $18 \%$,

表-1 本研究で使用される用語の定義

\begin{tabular}{l|l}
\hline 外来部待合空間 & 外来の患者が待つすべての空間を指す。 \\
\hline 総合待合 & 初診・再診受付, 会計, 薬局などの待合。 \\
\hline 各診療科待合 & それぞれの診療科ごとの待合。 \\
\hline 複合待合 & 総合待合と各診療科待合の区別がない待合。 \\
\hline その他 & 上の 3 つの待合に属さないもの。休㮩所など。 \\
\hline
\end{tabular}




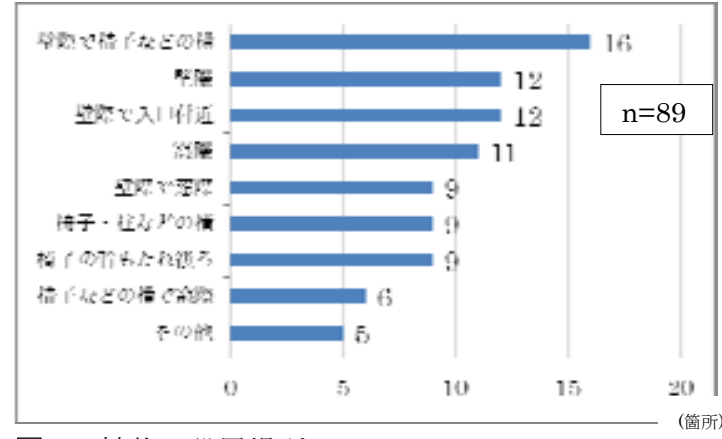

図-1 植物の設置場所

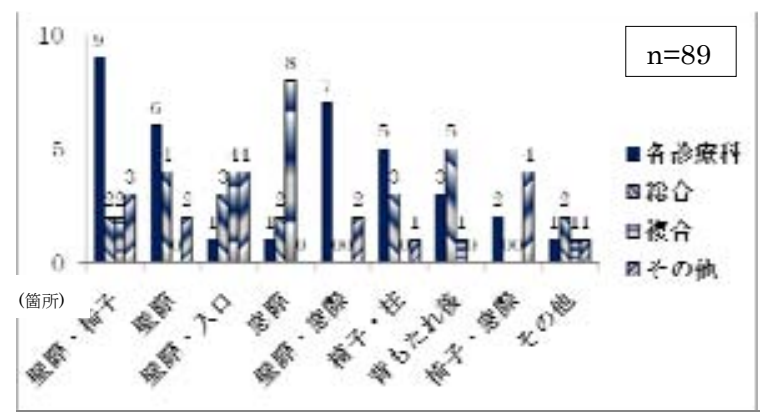

図-2 待合別の詳細な設置場所における植物の設置数

その他が 19 \%であった。図-2 は待合別の詳細な設置場所に おける植物の設置数のグラフである。この図をみると, 各診 療科待合では「壁際で入口付近」を除くすべての「壁際」の 項目で占める割合が最も大きく, また総合待合では「壁際で 入口付近」と「椅子の背もたれ後ろ」に植物が設置されてい る割合が大きいことがわかった。各診療科待合は通路状の形 態を, 総合待合はホール状の場所であることが多いためであ ると考えられた。特に総合待合では, 受付や会計の面積が多 くを占め，人の動線がかなり込み合うことから，外来部待合 では植物の設置場所が限定されてしまう傾向があると考えら れた。

次に設置されている植物種についてみてみると, 図-3より 椅子に座った状態で目線の高さ以上になる植物 $(60 \%)$ とそ れ以下の植物 (40\%) に分けられた。目線以下の植物は寄せ 植えや椅子の背もたれの後ろに配置されるものが多く, 赤
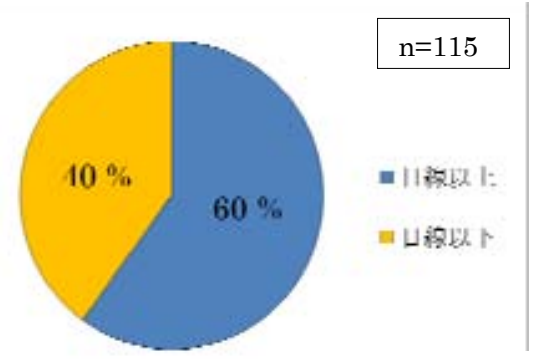

(\%)

図-3 樹高別の植物の割合

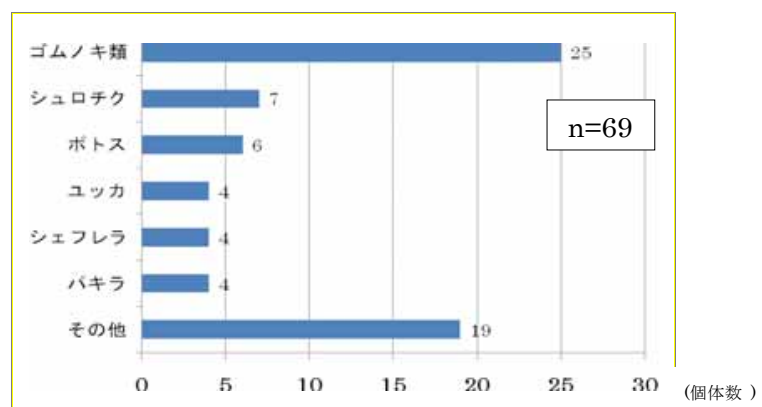

図-4 外来部待合に設置されている, 樹高が目線以上の植物数
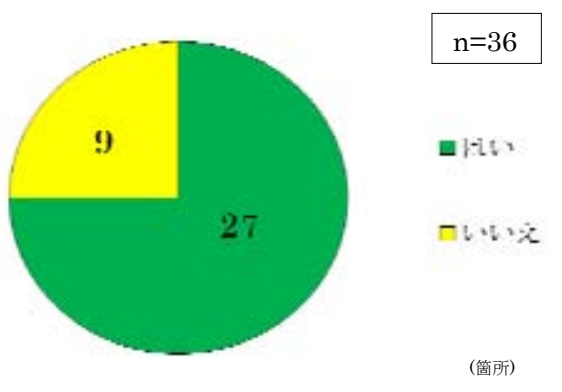

図-5 植物の設置の現状

や黄などの色や, 模様のある葉をもつ草本植物がほとんどで あった。一方，目線より高いものは $1.8 \mathrm{~m}$ 以上の樹木かつる 植物であった。植物種をみると図-4より，ゴムノキ類 (Ficus elastica Roxb. や Ficus lyrata Warb. など） が最も多く 36 $\%$, 次いでタケ類 (Rhapis humilis Bunt. や Rhapis excelsa A. Herry) , ポトス (Epipremnum aureum Bunt) であっ た。これら緑が濃く, 葉の密集した常緑樹や観葉植物は, 光 環境の悪い屋内でも生育可能なこと，また管理が容易である ことなどから，外来部待合空間において好んで設置されてい ると考えられた。

\section{2 アンケート調査結果}

図-5 に示すアンケートの結果から，外来部待合に植物があ ると答えた病院は全体の $75 \%$, ないと答えたのは $25 \%$ \% あ った。

図-6に植物の設置理由を聞いた結果を示した。植物を設置 する目的は，「患者の安らぎ」という回答が最も多く，続い て「病院内の美観の向上」, 「ストレス緩和効果を期待」と なっており，植物の設置はおもに患者のためであるというこ とがわかった。しかし，今後の植物の設置予定について聞い たところ，今後，「植物を増やしていく予定である」という 回答は $20 \%$ \%か見られなかった。

次に植物の維持管理について聞いた。その結果（図-7）, $50 \%$ 近くの病院が業者に委託しており, その理由としては 「管理の大変さ」が最も多く, $60 \%$ 近くを占めていた。

これらのことから, 病院側は患者のために外来に植物を設 置しているが，増やす予定はなく, 現状維持の考えを持つ病 


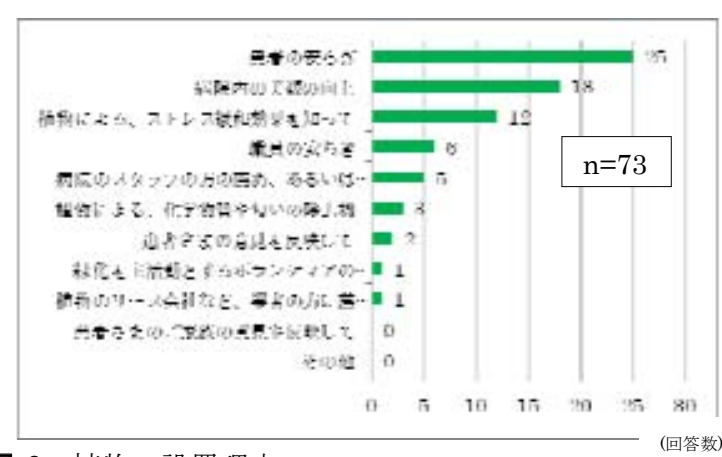

図-6 植物の設置理由

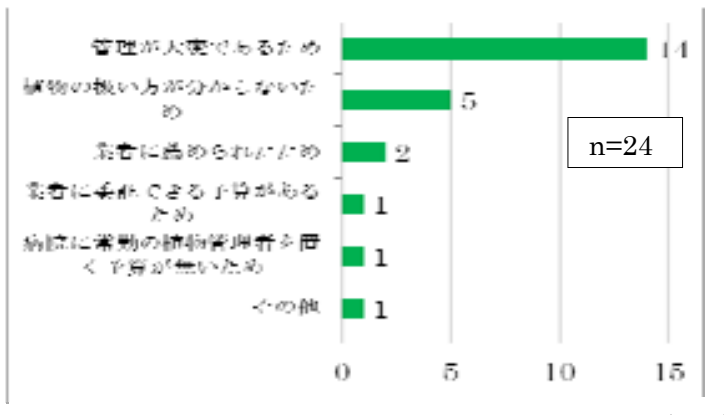

図-7＼cjkstart業者に管理を委託する理由

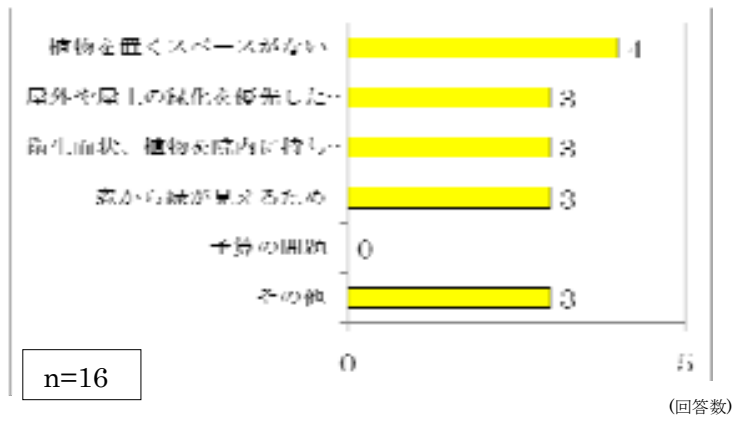

図-8 植物を置かない理由

院がほとんどであり，それは維持管理の大変さが一因である と考えられた。

植物を設置していないと答えた病院は，その理由としてス ペースの問題, 衛生上の問題など様々な項目が挙げられ，共 通した傾向は見られなかった（図-8）。既往の病院緑化の研 究では，今後植物を増やさない，また設置しない理由として

「予算の問題」が挙げられているが，今回の調査では，予算 を理由にしている病院は，見られなかった。「予算の問題」 が挙げられなかった理由の一つとして，屋外や屋上の緑化は 規模が大きく，大型樹木なども取り扱うことから維持管理の 負担，およびそれに伴う費用が大きくなると考えられる。そ れに対し，屋内の緑化は，観葉植物や小型の樹木の設置がほ とんどであり，リース会社などへの委託も多いことから，容 易に導入することができる。特に外来部待合においては，患 者への心理的効果だけでなく, 病院内の美観の向上を求めて

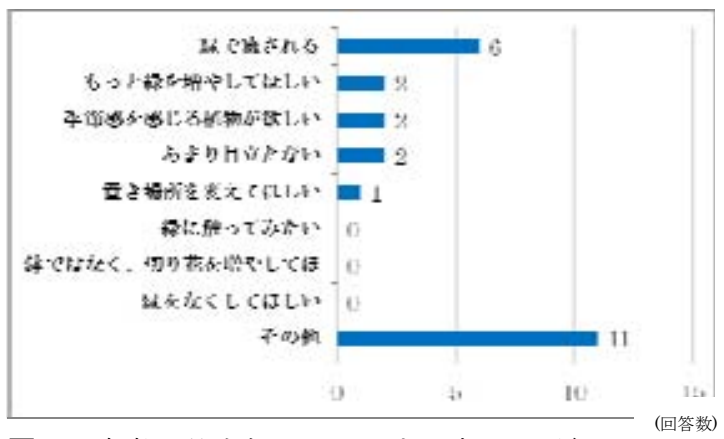

図-9 患者の外来部の緑に対する意見の詳細

植物を設置していることから（図-6），院内環境改善のため のアメニティとしての評価も高いと考えられた。

また外来部待合に植物を設置しているか否かにかかわらず に，患者に外来部待合の緑に対する意見を聞く機会があるか を尋ねたところ，「意見箱を設置している」と回答した病院 が 55 \%を占め，最も多いことがわかった。また「全くしてい ない」と回答した病院が $37 \%$ と多くみられたが，緑の意見箱 ではないという回答がいくつかみられる。したがって実際に は意見箱を設置しているが，緑に対するものではないと考え られた。このことから，外来部待合の緑に対する意見を汲み 取る仕組みが整っていない現状があると考えられた。

図-9 には意見箱などから，患者の緑に対する具体的な意見 の詳細をまとめた。グラフから「緑で癒される」といった緑 に対する評価や，「もっと緑を増やして欲しい」，「季節感 を感じる植物が欲しい」といった要望が 50 \%を占めているこ とがわかった。一方で「その他」の回答のほぼすべてが「緑 に対する意見はない」という回答であった。特に植物を設置 している病院の 8 力所が，意見がないと回答している。この ことから患者側からも意見が出にくいと考えられる。現地調 査の際に，意見箱の意見と回答が掲示されていたが，謝辞の 言葉や外来の待ち時間, 職員の応対に関するものがほとんど で，外来部の植物に関する意見はみられなかった。このこと から，患者自身が外来部待合の緑に関する意見を出すという 発想があまりないと考えられた。

\section{4. おわりに}

ガーデンホスピタル構想では精神的なストレス軽減を目的 に掲げていることから，待合で座った状態で植物が視認でき ることが重要である。よって主な評価項目として, 配置と設 置された植物の二つが重要であると考えられる。今回の現地 調査では，座った状態では視界に入りにくかったり，椅子の 背もたれの後ろに設置されていたり，人の行き来が多くて視 認できない植物の設置例が見られた。このような配置では, たとえ緑が多くても患者の精神的なストレスの軽減効果は期 待できない。また設置される植物も，椅子との位置関係によ って樹高や緑量などを調整する必要がある。これらは重要な 評価のポイントになる。 
今後は患者の植物に対する意識を把握した上で, 外来部待 合の緑化に反映させることが必要であると考えられた。

調査にあたり，アンケートに回答して頂きました千葉県の 病院の緑化担当者の皆様, また病院建築のアドバイスを頂き ました千葉大学大学院工学研究科の中山茂樹先生にはこの場 を借りてお礼を申し上げます。

\section{引用文献}

1）石井麻有子・岩崎 寛（2007）東京都と千葉県における地域 と設置者の違いによる病院緑化の現状と傾向, 日本緑化工学 会誌, 33(1)：258-261.

2) 岩崎 寛 (2004) 病院における緑化の現状と問題点一兵庫県 における事例, 日本緑化工学会誌，30(1)：352-355.

3）岩崎 寛（2005）景観園芸学入門, ビオシティ, pp. 158-169.
4）木本久美子（2004）病院における緑化の計画と管理に関する 基礎的研究, 千葉大学大学院自然科学研究科修士論文, pp. 37.

5）財団法人日本医療機能評価機構ホームページ

http://jcqhc.or.jp/html/index.htm（病院審査の種別）

http://www.report.jcqhc.or.jp/cgi-bin/kaisetu_td.cgi?page_i $\mathrm{d}=$ di050P\#kubun

6）社団法人日本医療福祉建築協会（2007）病院建築基礎講座, pp. 2-34.

7）高野麻美（2008）東京都および千葉県における病院の屋上の 緑化の現状と施設管理担当者の意識に関する研究, 日本緑化 工学会誌, 34(1) : 319-322.

8) 千葉県健康福祉部医療整備課（2007）千葉県病院名簿（平成 19 年 4 月 1 日現在）.

9）辻吉隆 (2008)「ガーデンホスピタル」構想, 日本緑化工学 会シンポジウム「病院緑化の最前線」要旨集 : 3-33.

(2009. 7. 15 受理) 